Conference Paper

\title{
Synthesis of Edible Film from Crab Shell Chitosan and Banana Peel Starch
}

\author{
Sintha Soraya Santi *, Ayu Puspita Kandhi Hariyanto, Muhamad Dendy Hartono \\ Department of Chemical Engineering, Engineering Faculty, Universitas Pembangunan Nasional "Veteran" \\ Surabaya, East Java, Indonesia
}

*Corresponding author:

E-mail: sintha.tk@upnjatim.ac.id

\begin{abstract}
Nowadays the use of plastics has become an important material so that the demand for home products as well as in industrial production is increasing. The activity of using plastics is increasing, causing complex environmental problems because it's non-biodegradable. One of the biodegradable plastics is an edible film, which is a thin layer as a food packaging or coating which can be consumed together with the packaged product. In this research, the edible film was made using a synthesis method with raw materials such as crab shell chitosan, banana peel starch, and glycerol. Chitosan effects film reinforcement, starch functions as a film matrix former and glycerol also functions to increase the flexibility of the film. Through this research, it is hoped that the ratio of raw materials for the edible film including starch, chitosan, and glycerol can affect the characteristics of edible film such as tensile strength, percent elongation, percent of the solubility value in water.
\end{abstract}

Keywords: edible, film, chitosan, starch, glycerol

\section{Introduction}

Food product packaging is a process of wrapping with appropriate packaging materials to maintain and protect food into the hands of consumers so that its quality and safety can be maintained. One of the packaging materials that are often used is plastic which in addition to containing dangerous chemicals, its use also has many contributions that are difficult to decipher. Increasing public awareness of health and environmental problems, increasing demand for biodegradable packaging that can ensure the safety of food products (Kusumawati \& Putri, 2013).

Biodegradable packaging can be made from organic materials from nature, for example, a mixture of chitosan and starch. The edible film is a biodegradable packaging. The edible film is a thin layer that functions as a food packaging or coating which can be consumed together with the packaged product. This type of coating material functions as an inhibitor of mass transfer (for example moisture, oxygen, fat, and solutes) and or as a barrier to food ingredients or additives and/or to improve food handling (Sari, 2017). As a biodegradable material, the edible film can be the best answer needed to tackle environmental pollution (Volpe, 2014). Natural polymers can be an alternative source for packaging development because of their palatability and biodegradability when compared to synthetic plastics which are non-biodegradable and pollute the environment because they are difficult to decompose, not like edible films or biodegradable plastics. Edible films are emerging as an alternative to synthetic plastics for food applications and have been accepted by some in recent years because of their superiority over synthetic films. The main advantage of the edible film compared to synthetic plastics is that the edible film has no parts that can be thrown away and even if it is not consumed, it is still environmentally friendly. Applications for the use of edible films include being used as wrappers for candy, sausage, instant noodle seasoning, fruit, food, salads, and dry soups (Cornelia, Anugrahati, \& Christina, 2012).

\section{How to cite:}

Santi, S. S., Hariyanto, A. P. K., \& Hartono, M. D. (2020). Synthesis of edible film from crab shell chitosan and banana peel starch. $1^{\text {st }}$ International Conference Eco-Innovation in Science, Engineering, and Technology. NST Proceedings. pages 158-164. doi: 10.11594/ nstp.2020.0524 
Based on the Japanese Industrial Standard, the mechanical properties of the edible film can be seen from the tensile strength, elongation, and thickness values. The standard value of tensile strength for the edible film is $0.392 \mathrm{Mpa}$. Then, the elongation value is at least 10 percent and the thickness is a maximum of $0.25 \mathrm{~mm}$.

According to the records of the Ministry of Marine Affairs and Fisheries in 2000, Cold Storage (a fish processing company) said that the amount of by-products in the crab canning factory in the form of crab heads, skins, tails, and legs is generally $25-50 \%$ of the weight, and very abundant. This by-product, in Indonesia, has not been widely used so that it only becomes waste that disturbs the environment, especially the effect of unpleasant odors and water pollution, namely the content of BOD 5, COD, and TSS in the waters around the chitin factory which is quite high. Crab contains the highest percentage of chitin (70\%) among the crustaceans, insects, worms, and fungi. The chitin contained will be processed into chitosan which can be used as an ingredient in edible film synthesis (Trisnawati, Andesti, \& Saleh, 2013). Chitosan is a compound with the chemical formula poly (2-amino-2-dioxy- $\beta$-D-Glucose) which can be produced by hydrolysis of chitin using a strong base (Hargono, Abdullah, \& Sumantri, 2008). Then the source of starch that can be used comes from banana peels which contain about $18.5 \%$ starch. Banana peel waste is generally disposed of together with kitchen waste and usually, in handling, the waste will be buried in a landfill which can produce $\mathrm{CH}_{4}$ and $\mathrm{CO}_{2}$ compounds. These compounds are certainly dangerous for the environment (Agustin \& Padmawijaya, 2016).

Glycerol is a type of plasticizer used to make edible films. Glycerol has a cheap purchase value. It is also available and is a material that can be renewed so that it does not pollute the environment. According to research from (Jacoeb, Nugraha, \& Utari, 2014) who researched Making Edible Film from Lindur Fruit Starch with the Addition of Glycerol and Carrageenan, it was found that the difference in thickness values was caused by the nature of glycerol, carrageenan, and starch which are both hydrophilic so they bind more water which will evaporate after the oven process and glycerol which has a lower boiling point than other materials, the resulting edible film is getting harder and stiffer.

This research discusses the synthesis of edible film from chitosan from crab shells and banana peel starch, as an alternative to plastic which has biodegradable properties and is certainly not dangerous. Also, the reason for choosing the edible film raw material is because it can be taken from wastes which, if left alone or improperly handled, can pollute the environment, so that by treating this waste it can reduce environmental pollution.

\section{Research Method}

Food product packaging is a process of wrapping with appropriate packaging materials to maintain and protect food into the hands of consumers so that its quality and safety can be maintained. One of the packaging materials that are often used is plastic which in addition to containing dangerous chemicals, its use also has many contributions that are difficult to decipher. Increasing public awareness of health and environmental problems, increasing demand for biodegradable packaging that can ensure the safety of food products (Kusumawati \& Putri, 2013).

Biodegradable packaging can be made from organic materials from nature, for example, a mixture of chitosan and starch. The edible film is a biodegradable packaging. The edible film is a thin layer that functions as a food packaging or coating which can be consumed together with the packaged product. This type of coating material functions as an inhibitor of mass transfer (for example moisture, oxygen, fat, and solutes) and or as a barrier to food ingredients or additives and/or to improve food handling (Sari, 2017). As a biodegradable material, the edible film can be the best answer needed to tackle environmental pollution (Volpe, 2014). Natural polymers can be an alternative source for packaging development because of their palatability and biodegradability when compared to synthetic plastics which are non-biodegradable and pollute the environment because they are difficult to decompose, not like edible films or biodegradable plastics. Edible 
films are emerging as an alternative to synthetic plastics for food applications and have been accepted by some in recent years because of their superiority over synthetic films. The main advantage of the edible film compared to synthetic plastics is that the edible film has no parts that can be thrown away and even if it is not consumed, it is still environmentally friendly. Applications for the use of edible films include being used as wrappers for candy, sausage, instant noodle seasoning, fruit, food, salads, and dry soups (Cornelia, Anugrahati, \& Christina, 2012).

Based on the Japanese Industrial Standard, the mechanical properties of the edible film can be seen from the tensile strength, elongation, and thickness values. The standard value of tensile strength for the edible film is $0.392 \mathrm{Mpa}$. Then, the elongation value is at least 10 percent and the thickness is a maximum of $0.25 \mathrm{~mm}$.

According to the records of the Ministry of Marine Affairs and Fisheries in 2000, Cold Storage (a fish processing company) said that the amount of by-products in the crab canning factory in the form of crab heads, skins, tails, and legs is generally $25-50 \%$ of the weight, and very abundant. This by-product, in Indonesia, has not been widely used so that it only becomes waste that disturbs the environment, especially the effect of unpleasant odors and water pollution, namely the content of BOD 5, COD, and TSS in the waters around the chitin factory which is quite high. Crab contains the highest percentage of chitin (70\%) among the crustaceans, insects, worms, and fungi. The chitin contained will be processed into chitosan which can be used as an ingredient in edible film synthesis (Trisnawati, Andesti, \& Saleh, 2013). Chitosan is a compound with the chemical formula poly (2-amino-2-dioxy- $\beta$-D-Glucose) which can be produced by hydrolysis of chitin using a strong base (Hargono, Abdullah, \& Sumantri, 2008). Then the source of starch that can be used comes from banana peels which contain about $18.5 \%$ starch. Banana peel waste is generally disposed of together with kitchen waste and usually, in handling, the waste will be buried in a landfill which can produce $\mathrm{CH}_{4}$ and $\mathrm{CO}_{2}$ compounds. These compounds are certainly dangerous for the environment (Agustin \& Padmawijaya, 2016).

Glycerol is a type of plasticizer used to make edible films. Glycerol has a cheap purchase value. It is also available and is a material that can be renewed so that it does not pollute the environment. According to research from (Jacoeb, Nugraha, \& Utari, 2014) who researched Making Edible Film from Lindur Fruit Starch with the Addition of Glycerol and Carrageenan, it was found that the difference in thickness values was caused by the nature of glycerol, carrageenan, and starch which are both hydrophilic so they bind more water which will evaporate after the oven process and glycerol which has a lower boiling point than other materials, the resulting edible film is getting harder and stiffer.

This research discusses the synthesis of edible film from chitosan from crab shells and banana peel starch, as an alternative to plastic which has biodegradable properties and is certainly not dangerous. Also, the reason for choosing the edible film raw material is because it can be taken from wastes which, if left alone or improperly handled, can pollute the environment, so that by treating this waste it can reduce environmental pollution.

\section{Results and Discussion \\ Mechanical properties tensile strength and elongation of edible film}

Tensile strength is the maximum pressure a film can withstand before breaking. This is one of the mechanical characteristics of the edible film which has an important role in protecting the product it is coated with, during the product handling and marketing process. Based on the results of the research that has been done, it can be seen in Figure 1. that the more chitosan composition in the edible film, the higher the tensile strength of the edible film. The hydrogen bonds formed in the plastic film make the plastic film stronger and difficult to break. Meanwhile, the more starch composition in the edible film, the lower the tensile strength of the edible film. This is following the results of previous research by (Agustin \& Padmawijaya, 2016) where the greater the composition of chitosan, the tensile strength value will increase. Dissolved chitosan concentration affects the number of hydrogen interactions both inter and intramolecular in chitosan. Also, chitosan has 
a linear polymer chain structure, where the linear chain structure tends to form a crystalline phase. The crystalline phase can provide strength but causes the film to become more brittle so it breaks easily.

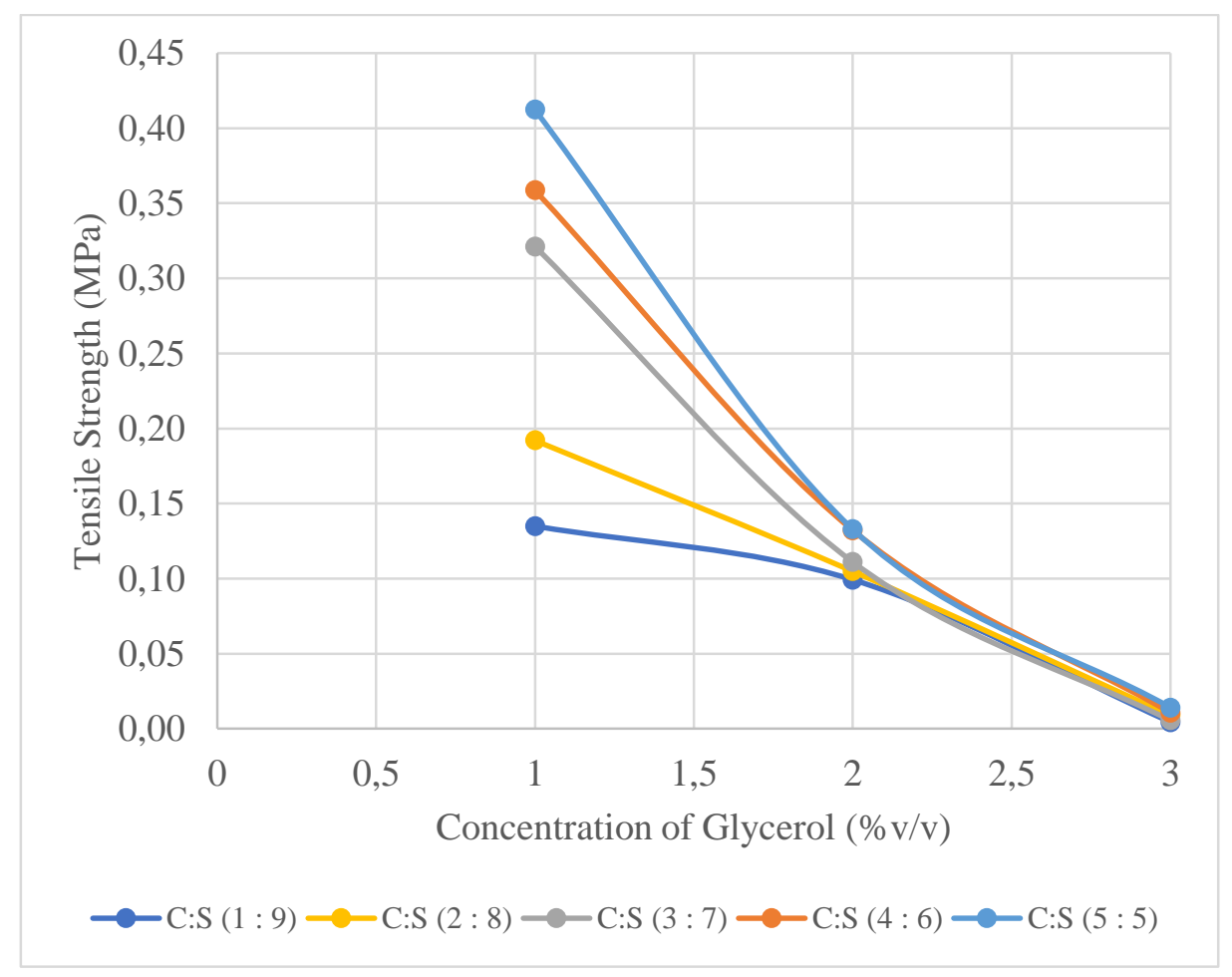

Figure 1. Effect of glycerol percentage to the tensile strength of the edible film

Then from Figure 1. For the effect of the glycerol composition, the more glycerol composition is obtained, the lower the tensile strength value. These results are supported by research conducted by (Gontard et al., 1994) where the addition of glycerol will reduce intermolecular bonds between polymer chains thereby reducing film stiffness and increasing polymer mobility. Plasticizer causes a reduction in the interaction of inter and intramolecular hydrogen bonds in the polymer chain so that the film matrix formed will be weaker.

The results of the tensile strength (see Table 1). The results showed the highest tensile strength with a chitosan-starch ratio of 5: 5 and a glycerol concentration of $1 \%$, which was 0.4123 MPa. The lowest yield was shown in the chitosan-starch ratio 1: 9 and the glycerol concentration of $3 \%$, which was $0.0043 \mathrm{MPa}$. In general, the tensile strength of the edible film produced in this research meets the minimum standard for the tensile strength of edible films based on the Japanese Industrial Standard, namely $0.3923 \mathrm{MPa}$ only at a 5: 5 chitosan-starch ratio and $1 \%$ glycerol concentration.

Elongation is the percentage change in film length that is calculated when the film is stretched until it breaks. Based on the results (see Figure 2) of the research that has been done, it was found that the more the starch composition in the edible film, the lower the percentage value of elongation. Meanwhile, the more chitosan composition in the edible film, the higher the percentage value of elongation. This result is inversely proportional to the results of previous studies, one of which is in research by (Agustin \& Padmawijaya, 2016) where the greater the chitosan composition, the lower the elongation value. There are two main constituent components in starch, namely amylose which has a linear chain structure, and amylopectin whose chain structure is branched. This branched structure tends to form amorphous structures. When the plastic film is given a tensile 
load, the elongation starts from the amorphous part, where the amorphous phase is attracted and stretches to form a parallel arrangement.

Then, this occurs due to the chemical composition in bananas varies depending on the variety, and is supported by the research from (Zhang et al., 2005) so that the starch in bananas used in this study is not completely gelatinized. This is indicated by the presence of a little starch powder that remains or does not gelatinize when heated according to the gelatinization temperature of banana peel starch. Also, it is characterized by the edible film sheet which has greater flexibility with a lower starch composition and is stiffer with a high starch composition.

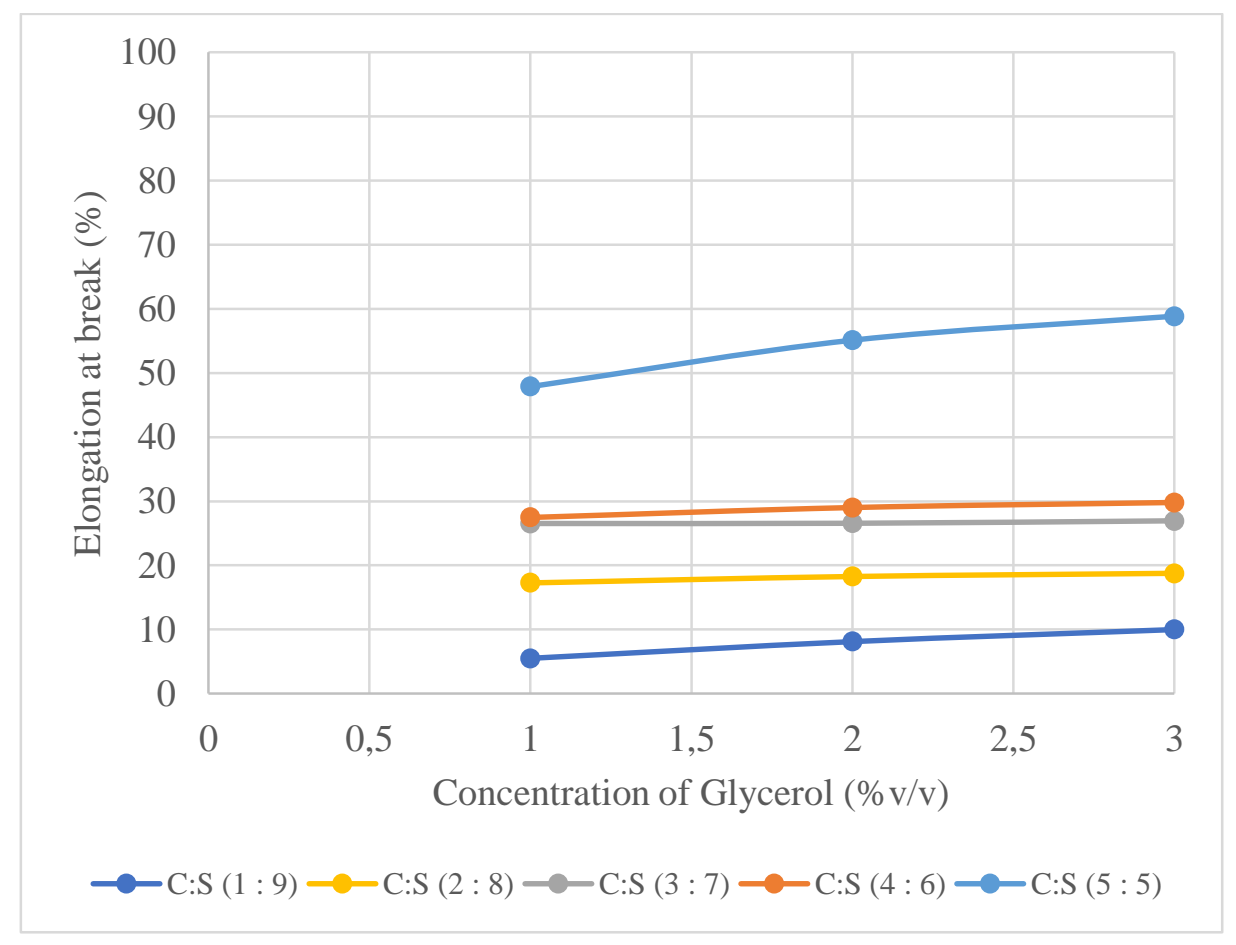

Figure 2. Effect of glycerol percentage to elongation at break of edible film

Then, for the effect of the glycerol composition, the more the glycerol composition, the higher the percentage value of elongation. This is following previous research conducted by (Jacoeb, Nugraha, Utari, 2014) that the greater the addition of a plasticizer, the longer the percentage of elongation will increase. Glycerol in its function as a plasticizer reduces the mechanical cohesion bond between polymers and can change its rigidity so that the film formed is more flexible. Glycerol has a small molecular weight so that it can join in the film matrix and increase the flexibility and ability to form the film. The more the plasticizer concentration, the smaller the cohesion between the polymers and the softer the film formed so that the edible film formed easily breaks.

The percentage value of elongation on edible films according to the Japanese Industrial Standard is at least $10 \%$. The highest yield was seen in chitosan-starch composition 5: 5 with a glycerol concentration of $3 \%$, which was $58.8470 \%$. However, the chitosan-starch composition of $1: 9$ with a glycerol concentration of $1 \%$ and $2 \%$ of the resulting elongation did not meet the minimum standards and was the lowest yield.

\section{The solubility of edible film}

Solubility is a physical property of the edible film which shows the percentage of dry weight dissolved after immersion in water for 7 days. The solubility of this film is strongly influenced by the source of the film's base material. An edible film that shows high solubility means that the film 
can be easily consumed. Generally, edible films are said to be safe for consumption if they have a solubility of more than $50 \%$ percent.

Chitosan which has free amino groups and has a solubility standard that only dissolves at $\mathrm{pH}$ $\leq 6$ makes the solubility of edible film decrease. This is reinforced by previous research by (Puspita et al., 2015) where the more chitosan is added, the solubility of edible will automatically decrease because of the hydrophobic chitosan which is difficult to absorb water. Then in other compositions such as starch according to research conducted by (Sakinah, 2018) states that usually natural starch is insoluble in cold water and most organic solvents include acetone, alcohol, and ether. However, it will become water-soluble when the dispersion is heated to a certain critical temperature which is called the gelatinization temperature. Gelatinization is a staple property of starch which is characterized by changes in physical and chemical properties. The gelatinization process is characterized by very large swelling, increased viscosity, translucency, and solubility. As the dispersion temperature increases, stirring will further increase the viscosity of the dispersion. These changes are often caused by breaking the hydrogen bonds in the starch grains which allow water to enter the granules to make them swell as the dispersion is heated.

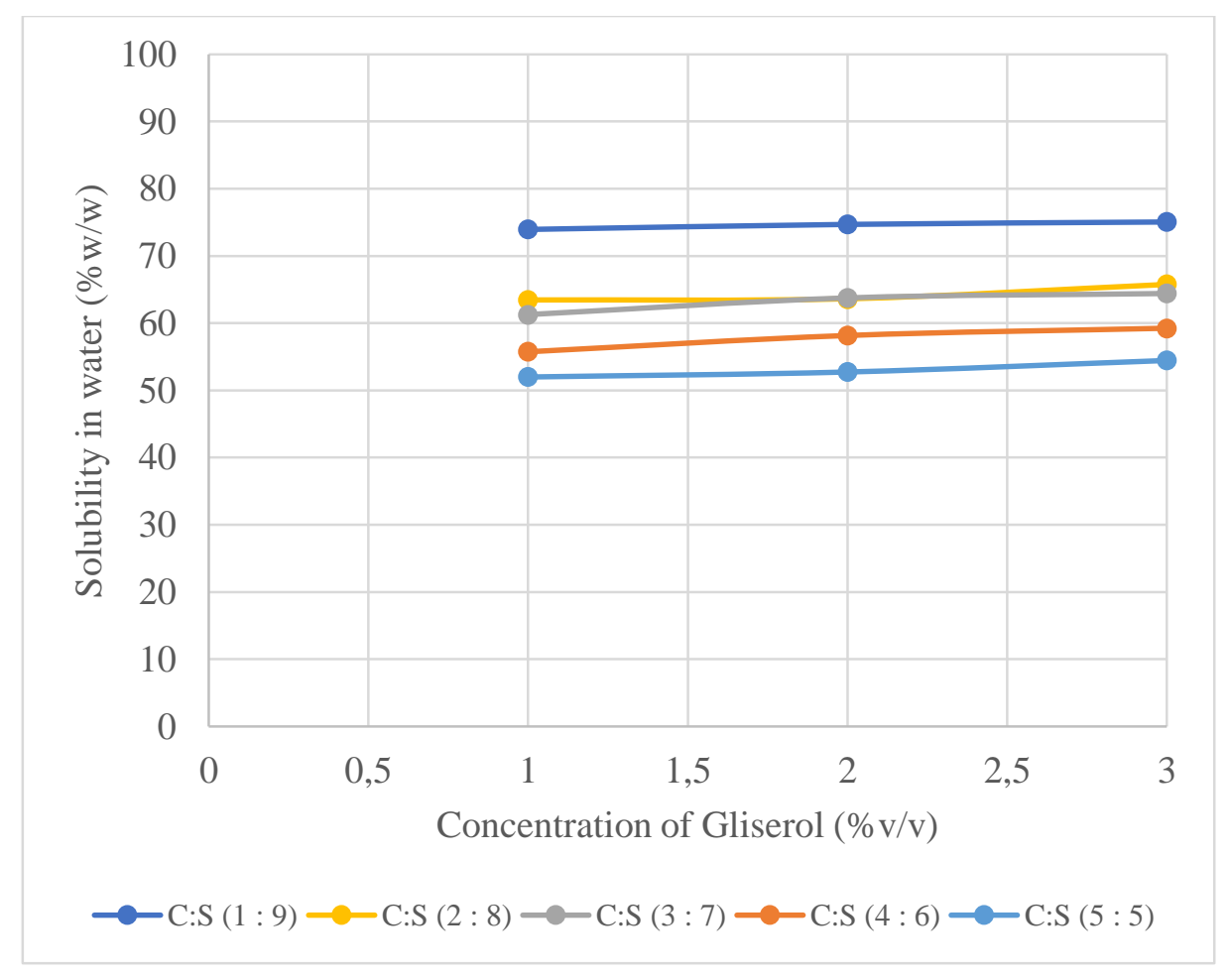

Figure 3. Effect of glycerol percentage to the solubility of edible film

From the solubility results (see Figure 3). that the solubility of the edible film increases with increasing glycerol concentration. Glycerol has hydrophilic properties that cause interactions with water molecules. This is reinforced by the relationship that increasing the amount of glycerol will increase the $\mathrm{O}-\mathrm{H}$ (hydrogen) bond in the film matrix. The solubility results of the edible film can be seen in table 6 where the highest solubility yield was found in the chitosan-starch ratio 1: 9 and glycerol $3 \mathrm{ml}$, which was 75.0463\%. And the lowest yield was obtained at a 1: 1 chitosanstarch ratio with $1 \mathrm{ml}$ glycerol, which was $51.9868 \%$. Overall, the percent solubility of edible films produced in this research has met the standards based on previous research by (Gontard et al., 1994) where the solubility of edible films is stated to be at least $50 \%$.

\section{Conclusion}


Based on the research results that have been obtained, it can be concluded that the edible film from a mixture of crab shell chitosan and banana peel starch with the addition of glycerol can be produced using the synthesis method. The resulting edible film has different characteristics depending on the variation in the ratio between starch and chitosan and the concentration of glycerol, where these characteristics include tensile strength, elongation percent, and solubility percent and almost entirely following the Japanese Industrial Standard (JIS) and existing theories. The edible film results in the highest value of tensile strength of 0,4123 MPa at chitosan and starch ratio 5:5 with glycerol addition $1 \%$, and the highest elongation obtained is $58,8470 \%$ at chitosan and starch ratio 5:5 with glycerol addition 3\%. The physical property of edible film resulted from the best solubility test with chitosan and starch ratio 1:9 with glycerol addition is $3 \%$.

\section{Acknowledgment}

We gratefully acknowledge the Chemical Engineering Department, Engineer Faculty, UPN "Veteran" Jawa Timur for the facilities.

\section{References}

Agustin, Y. E., \& Padmawijaya, K. S. (2016). Sintesis bioplastik dari kitosan-pati kulit pisang kepok dengan penambahan zat aditif. Jurnal Teknik Kimia, 10(2), 43-51.

Cornelia, M., Anugrahati, N. A., \& Christina, C. (2012). Pengaruh penambahan pati bengkoang terhadap karakteristik fisik dan mekanik edible film. Jurnal Kimia dan Kemasan, 34(2), 263-271.

Gontard, N., Duchez, C., Cuq, J. L., \& Guilbert, S. (1994). Edible composite films of wheat gluten and lipids: water vapour permeability and other physical properties. International Journal of Food Science \& Technology, 29(1), 39-50.

Jacoeb, A. M., Nugraha, R., \& Utari, S. P. S. D. (2014). Pembuatan edible film dari pati buah lindur dengan penambahan gliserol dan karaginan. Jurnal Pengolahan Hasil Perikanan Indonesia, 17(1), 14-21.

Hargono, H., Abdullah, A., \& Sumantri, I. (2008). Pembuatan kitosan dari limbah cangkang udang serta aplikasinya dalam mereduksi kolesterol lemak kambing. Reaktor, 12(1), 53-57.

Kusumawati, D. H., \& Putri, W. D. R. (2013). Karakteristik fisik dan kimia edible film pati jagung yang diinkorporasi dengan perasan temu hitam. Jurnal Pangan dan Agroindustri, 1(1), 90-100.

Puspita, N. F., Altwaya, S., Mawarani, L. J., Ayu, D. and Rosita, D. (2015). The effect of the addition of glycerol and chitosan in the biodegradable plastics production from porang flour. Proceedings of The 9th Joint Conference on Chemistry, 312-316.

Sakinah, A. R. (2018). Isolasi, karakterisasi sifat fisikokimia, dan aplikasi pati jagung dalam bidang farmasetik. Farmaka, 16(2), 430442.

Sari, D.A., (2017). Kajian karakteristik pembuatan edible film dengan kombinasi pati biji nangka dan alginat sebagai pengemas makanan berbasis biodegradable. Jurnal Pangan dan Gizi, 7(2), 124-131.

Trisnawati, E., Andesti, D. and Saleh, A. (2013). Pembuatan kitosan dari limbah cangkang kepiting sebagai bahan pengawet buah duku dengan variasi lama pengawetan. Jurnal Teknik Kimia, 19(2), 17-26.

Volpe, A., 2004. il ciclo di vita delle località turistiche: sviluppi e limiti di un'economia posizionale vol. 17. Roma : Franco Angeli.

Zhang, P., Whistler, R. L., BeMiller, J. N., \& Hamaker, B. R. (2005). Banana starch: production, physicochemical properties, and digestibility. Carbohydrate Polymers, 59(4), 443-458. 